\title{
Cost And Time Performance Analysis With Concept Of Earned Value (Case Study Jakarta-Cikampek II Elevated Project)
}

\author{
Noviawati, PUSPITA \\ Faculty of Engineering, University Mercu Buana Jakarta, Indonesia \\ noviawatipuspita@gmail.com \\ Yopi, Lutfiansyah \\ Faculty of Engineering, University Mercu Buana Jakarta, Indonesia \\ Yopi.lutfiansyah@mercubuana.ac.id
}

\begin{abstract}
The research procedure starts with conducting a literature study, collecting data, and summarizing the results of gathering existing data. The purpose of this study is to evaluate the deviation of costs and time, calculate the estimated cost and time needed to complete the project work, calculate the estimated profit or loss that may occur in the completion of the project. Variants emphasized here are to investigate deviations in costs or planned schedules that have been planned or determined. The results of the analysis in JakartaCikampek II Elevated Project stated that in July 2019 the SPI value was $0.96<1$ which could be interpreted that the project progress had been delayed and the CPI value was 1.44>1 which could be interpreted that the actual the project cost is still smaller than the total budget cost. Estimated total costs up to the end of the project in the amount of Rp.2,694,413,965,781 of the total budget cost of Rp. 3,872,143,387,752 can save Rp. $1,177,729,421,971$. As for the estimated time to finish until the end of the project which is for 918 days from the time of the 915 day contract, there will be a delay of 3 days.
\end{abstract}

Keywords: Earned Value Analysis, Schedule Performance Index, Cost Performance Index

\section{INTRODUCTION}

The Jakarta-Cikampek II elevated Project is one of the largest projects in which it has many elements. The President Director of PT Jasa Marga stated in the interview that the traffic on the Jakarta-Cikampek toll road averaged 150,000 vehicles / day, it is normal if there are three lanes of 35,000 vehicles / day, therefore new toll roads must be built [1]. The project is scheduled for completion on March 27, 2019. But in reality the project has been delayed and has to be extended. In the 28th month there was a progress deviation of $3.66 \%$ with a difference in the cost of Rp.141,569,173,010 to the contract after the addendum of extended time. This delay is of course influenced by a number of factors which ultimately have an impact on completion of implementation time and expense.

Control of a project must be carried out from the beginning until the project is completed. This control is one way to keep the work going according to plan and not experience losses both in terms of time and cost. There are several concepts, one of which is earned value analysis. The concept of earned value presents three dimensions, namely the physical completion of the project, the actual costs already incurred, and what is obtained from the costs that have been incurred. Of the three dimensions can be connected between cost and time performance derived from the calculation of cost and time variants [5]. By using this earned value method, can the project complete the work on time and does the cost required to settle the remaining work be added or not. This is also certainly a way to evaluate the project as learning for further projects.

The Purpose of this research is : 
1. To know the project performance in terms of cost and time in the Jakarta-Cikampek II Elevated project.

2. To Know the estimated costs and time needed to complete the project.

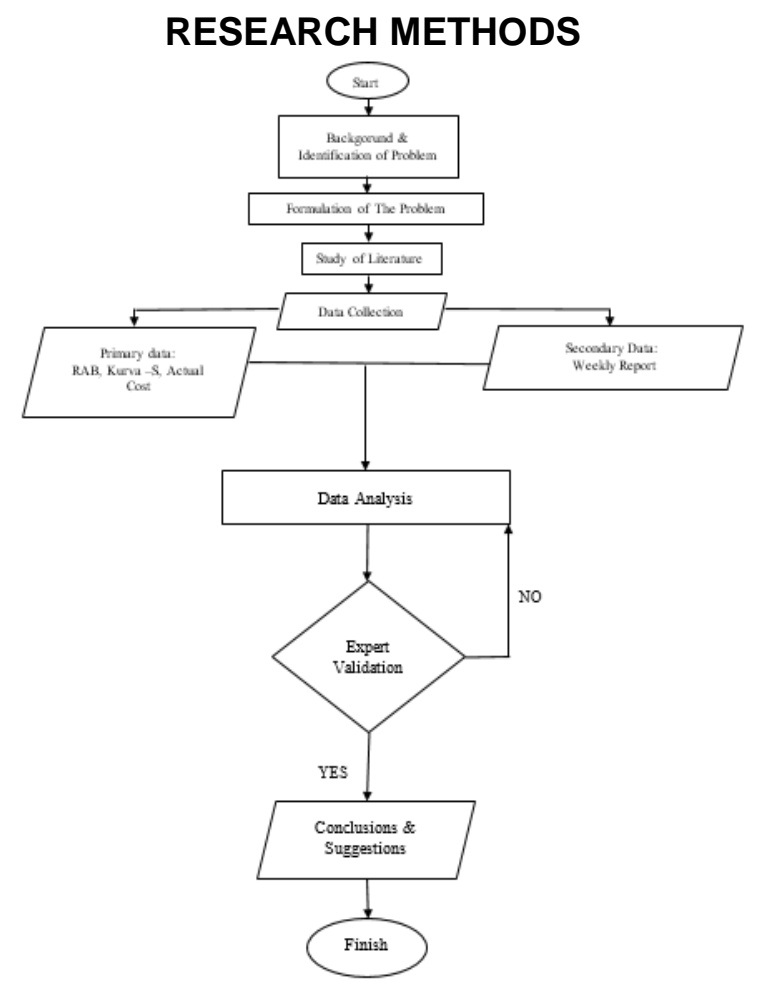

Fig. 1 Flow Chart

Source: Data in research, 2019

To solve that problem, it needs several steps as follows:

1. Start

2. Background and identification of problems

3. Formulation of the problem

4. Study of literature

5. Data Collection:
a. Primary data : RAB, Kurva-S, Actual Cost
b. Secondary data: Weekly report

6. Data analysis:
a. Calculating of BCWS, BCWP, and ACWP
b. Calculating of Schedule Varians dan Cost Varians
c. Calculating of Cost Performance Index and Schedule Performance Index
d. Calculating of Budget Estimate to Complete and Budget Estimate at Completion
e. Calculating of Schedule Estimate to Complete and Schedule at Completion

7. Expert Validation : Project Engineering Manager, Planning Manager, Chief Quantity Surveyor

8. Finish

\section{RESULTS AND DISCUSSION}

\section{Budgeted Cost of Work Schedule (BCWS)}

Budgeted Cost of Work Schedule is a budget that is allocated based on a work plan that has been prepared against time.

-Until July 2019 (28th Month)

BCWS $=\%$ Progress Plan $x$ Total Budget 
BCWS $=92,20 \%$ x Rp. 3,872,143,387,753 = Rp. 3,570,215,975,282,-

\section{Actual Cost Work Performance (ACWP)}

Actual costs are real costs that have been incurred by the project for a certain period to be used as direct and indirect costs.

-Until July 2019 (28th Month)

ACWP $=$ Rp. 2,385,808,815,085

\section{Budget Cost Work Performance (BCWP)}

Budget Cost Work Performance is the value received from completing work over a certain period of time.

-Until July 2019 (28th Month)

BCWP $=\%$ Progress Actual $\times$ Total Budget

$\mathrm{BCWP}=88,55 \% \times$ Rp. 3,872,143,387,752 = Rp. 3,428,646,802,272,-

\section{Cost Varians (CV)}

Cost Variance is the difference between the value obtained after completing work packages with the actual costs during the project implementation.

-Until July 2019 (28th Month)

$\mathrm{CV}=\mathrm{BCWP}-\mathrm{ACWP}$

$C V=$ Rp. $3,428,646,802,272-$ Rp. $2,385,808,815,085=$ Rp. $1,042,837,987,187,-$

\section{Schedule Varians (SV)}

Schedule Variance is the difference between the value obtained after completing work packages with the progress plan

-Until July 2019 (28th Month)

$\mathrm{SV}=\mathrm{BCWP}-\mathrm{BCWS}$

$S V=$ Rp. $3,428,646,802,272-$ Rp. $3,570,2125,975,282=$ Rp. $-141,569,173,010$

\section{Cost Performance Index (CPI)}

Cost efficiency factors that have been incurred in project implementation can be shown by comparing the value of work that has been physically completed (BCWP) with costs that have been incurred in the same period (ACWP).

-Until July 2019 (28th Month)

$C P I=\frac{B C W P}{A C W P}=\frac{R p \cdot 3,428,646,802,272}{R p \cdot 2,385,808,815,085}=1,44$

\section{Schedule Performance Index (SPI)}

The performance efficiency factor in completing work can be shown by the comparison between the value of work that has been physically completed (BCWP) with planned expenditure of expenses based on the work plan (BCWS).

-Until July 2019 (28th Month)

$S P I=\frac{B C W P}{B C W S}=\frac{R p \cdot 3,428,646,808,272}{R p \cdot 3,570,215,975,282}=0,96$

\section{Budget Estimate to Complete (BETC)}

BETC is an estimate of the costs required to complete the remaining work, so BETC is the remaining work budget divided by the cost performance index.

-Until July 2019 (28th Month)

$$
\begin{aligned}
& B E T C=\frac{(B A C-B C W P)}{C P I} \\
& B E T C=\frac{(R p \cdot 3,872,143,487,753-R p \cdot 3,428,646,802,272)}{1,44}
\end{aligned}
$$


$B E T C=R p \cdot 308,605,150,696$

\section{Budget Estimate at Completion (BEAC)}

$B E A C$ is the total expenditure until the time of reporting plus estimated costs for remaining work.

-Until July 2019 (28th Month)

$B E A C=A C W P+B E T C$

$B E A C=R p \cdot 2,385,808,815,085+R p .308,605,150,696$

$B E A C=R p \cdot 2,694,413,965,781$

\section{Schedule Estimate to Complete (SETC)}

SETC is the estimated remaining time needed to complete the work.

-Until July 2019 (28th Month)

SETC $=\frac{\text { Total Implementation Time }- \text { Time Spent }}{\text { SPI }}$

SETC $=\frac{(915-854)}{0,96}=64$ days

\section{Schedule Estimate at Completion (SEAC)}

SEAC is the amount of time the work was carried out until the time of reporting plus the estimated time needed to complete the remaining work.

-Until July 2019 (28th Month)

SEAC $=$ Time Spent + SETC

SEAC $=854+64=918$ days

Table 1. Calculation EVM

\begin{tabular}{|c|c|c|}
\hline Calculation & $\begin{array}{c}\text { Until July } 2019\left(28^{\text {th }}\right. \\
\text { Week })\end{array}$ & Note \\
\hline BCWS & Rp. 3,570,215,975,282 & \\
\hline ACWP & Rp. 2,385,808,815,085 & \\
\hline BCWP & Rp. $3,428,646,802,272$ & \\
\hline Cost Varians & Rp. 1,042,837,987,187 & $\begin{array}{l}\text { (+) Actual Cost are below Budget } \\
\text { Cost }\end{array}$ \\
\hline Schedule Varians & Rp. $-141,569,173,010$ & (-) The project has been delayed \\
\hline Cost Performance Index & 1,44 & $\begin{array}{l}\mathrm{CPI}>1 \text { (Cost performance is } \\
\text { good) }\end{array}$ \\
\hline Schedule Performance & 0,96 & $\mathrm{SPI}<1$ (time performance is bad) \\
\hline Index & & \\
\hline BETC & Rp. 308,605,150,696 & \\
\hline BEAC & Rp. 2,694,413,965,781 & \\
\hline SETC & 64 days & \\
\hline SEAC & 918 days & \\
\hline
\end{tabular}

Source: Data in research, 2019 


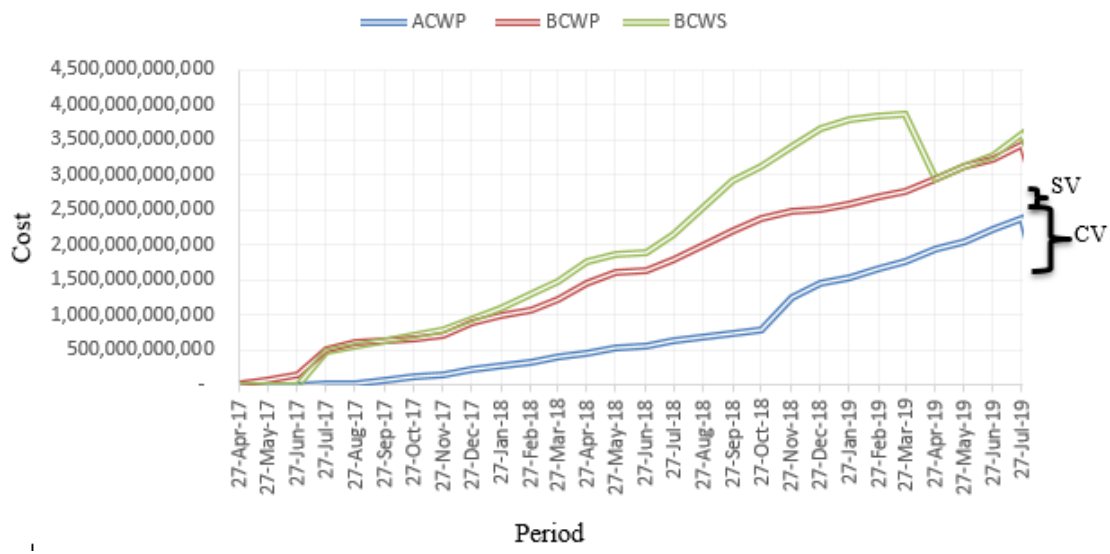

Figure 2. Chart Earned Value

Source: Data in research, 2019

According the Figure 2 above, it can be seen at the end of July (28th month) the value of BCWS> BCWP, which can be interpreted that the actual progress is delayed from the progress plan with a difference (SV) of Rp.-141,569,173,010. For the same period it can also be seen that the ACWP value <BCWP, it can be interpreted the amount of the budget that has been issued is smaller than the total budget cost with a difference (CV) of Rp. $1,042,837,987,187$

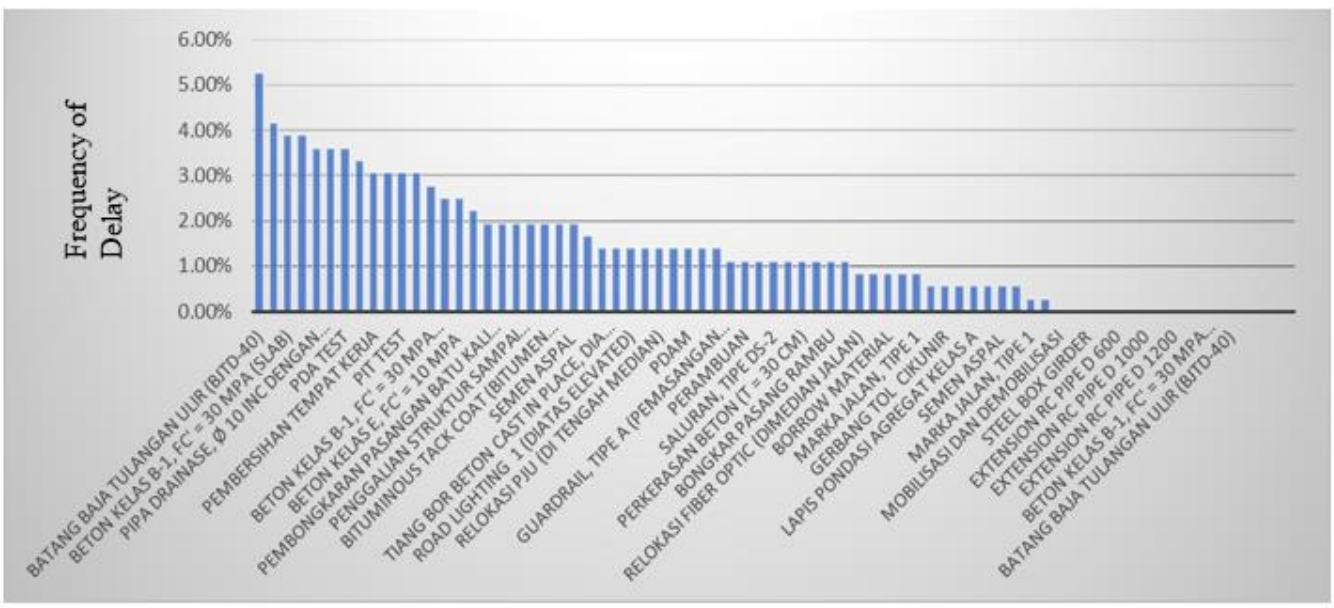

Work Item

Figure 3. Frequency of Delay

Source: Data in research, 2019 


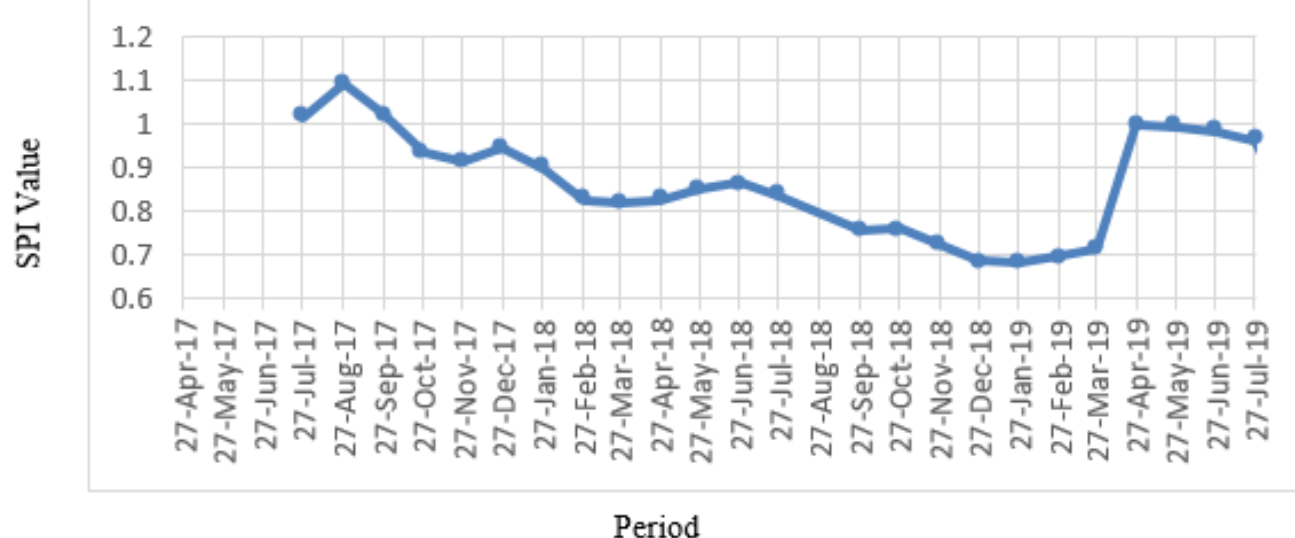

Figure 4: SPI Value

Source: Data in research, 2019

According to Figure-3 it can be seen that the frequency of work that experiences the most delays is reinforcing, slab concrete work and drainage pipe work. Because of delays in the work it will affect the next job. And in Figure-4 the smallest SPI value is found in January 2019 which is equal to 0.68 . This month there was a delay in the work of Slabs, drainage, double barriers, signs and PJU.

\section{CONCLUSION}

1. In July (28th month) the cumulative value of BCWS> BCWP with SV minus (-) in the amount of Rp.-141,569,173,010 and SPI value of $0,96<1$ which means that the project progress has been delayed. For the same period it can also be seen that the cumulative value of ACWP $<$ BCWP with a CV plus (+) value of Rp.1,042,837,987,187 and a CPI value of $1,44>1$ which can be interpreted that the actual cost of the project is still smaller than the total cost of the Budget.

2. Estimated total costs up to the end of the project (BEAC) in the amount of Rp.2,694,413,965,781 of the total budget cost of Rp.3,872,143,387,752 then can save Rp.1,177,729,421,971.-. As for the estimated time to finish until the end of the project (SEAC) which is for 918 days from the time of the 915 day contract, there will be a delay of 3 days.

\section{REFERENCES}

Aditiasari, Dana. (2016). Ini Manfaat Tol Jakarta-Cikampek Layang. https://finance.detik.com/berita-ekonomi-bisnis/d-3282385/ini/manfaat-tol-jakartacikampek-layang

Dubey, Anuj. (2015). Earned Value Analysis For A Construction Project.

Ervianto, W. (2006). Manajemen Proyek Konstruksi Yogyakarta: ANDI

Febri, E.R (2018). Analisis Kinerja Biaya dan Waktu dengan Metode Nilai Hasil (earned value analysis) pada Pekerjaan Renovasi Tahap II Asrama Wana Mulia SMK Kehutanan Samarinda.

Fleming, Q.W., Koppelman, J.M. (1994). The Essence and Evolution of Earned Value. AACE Transactions

Gasparotti, C., Raileanu,A., Rusu,E. (2017). The arned Value Manajemen- A Measure 
Technique of the Performance of the Costs and Labor in the Project.

Indryani, R., Maromi, M.I. (2015). Metode Earned Value untuk Analisa Kinerja Biaya dan Waktu Pelaksanaan pada Proyek Pembangunan Condotel De Vasa Surabaya.

Kurniawan, W., Purnomo, D., Astuti (2017). Analisis Earned Value Waktu dan Biaya proyek kontrstuksi Jalan (studi Kasus : Pelebaran Jalan Simpang Lago - Sorek I)

Manohar,A.R., Shetty,R.K. (2016). Project Performance Evaluation Through Earned Value Analysis.

Marfuah,U., Hidayat, M.Z. (2017). Perapan Project Control Process dengan Metode Earned Value Manajemen pada Proyek Pengadaan Kelambu Berinsektisida.

Padallar, M., Gopinath, S. Earned Value Analysis in Project Manajement : Survey and Research Potensial.

Pemerintah Indonesia. (2004). Undang-undang Nomor 38 Tahun 2004 tentang Jalan. Lembaran Negara RI Tahun 2004, No.4444. Sekretariat Negara. Jakarta.

Prisilia,H., Purnomo,D.A. (2019). Pengukuran Kinerja Biaya dan Waktu pada Proyek Terminal Pariwisata Terpadu Dengan Konsep Earned Value Analysis.

Priyo, M. (2012). Metode "Earned Value" Pada Jasa Konstruksi. Yogyakarta: Jurusan Teknik Sipil Universitas Muhammadiyah Yogyakarta.

Romadhonia, N., Aulady, M., Nuciferani, F. T. (2015). Pengukuran kinerja waktu dan biaya proyek pembangunan jetty menggunakan metode earned value

Suresh, Sandhya., Ramasamy, G.(2015). Analysis of Project Performance Using Earned Value Analysis.

Susanti, B., Melisah, Juliana, I. (2019). Penerapan konsep earned value pada proyek konstruksi jalan tol (studi kasus ruas jalan tol kayuangung - palembang - betung)

Triana, A. (2019). Analisis Kinerja Biaya dan Waktu dengan Konsep Earned Value Anaysis pada Proyek Bangunan Perkantoran di Kawasan Tebet Jakarta - Selatan.

Ulfah Nurdesse, P. (2019). Earned Value Analysis Pada Proyek Konstruksi (Studi Kasus Proyek Pembangunan Gedung R1 Ashley Hotel - Jakarta Pusat)

Wahyuni, E., Hendrawan, B.(2019). Analisis Kinerja Proyek "Y" menggunakan metode eraned value managment.

Wijaksana,B., Reresi, S.P. (2012) Analisis Biaya Proyek dengan Metode Earned Dalam Proses Kinerja. 